\title{
ACUTE MYOCARDITITS IN H1N1 INFLUENZA A VIRUS INFECTION
}

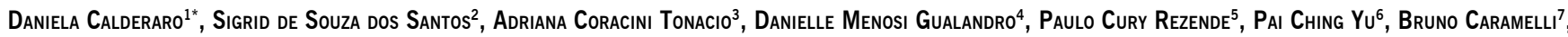 \\ YEH LI Ho ${ }^{8}$ \\ Study conducted at Interdisciplinary Medicine in Cardiology - Heart Institute (InCor) - University of São Paulo School of Medicine and Division of Infectious and \\ Parasitic Diseases - Hospital das Clínicas - University of São Paulo School of Medicine, São Paulo, SP
}

A 28 year-old man, previously healthy, was admitted to the emergency room with nine days of abdominal pain, myalgia, and headache. Two days after these initial symptoms, he developed high fever, cough and dyspnea. On physical examination he was tachycardic, tachypneic, hypoxemic ( $\mathrm{HbO} 2$ saturation breathing room air: 85\%), and hypotensive. Subsequently, he was transferred to the intensive care unit for hemodynamic control with vasopressors, invasive mechanical ventilation, and dyalisis. It should be emphasized that the patient was admitted to the hospital in July 2009, during the initial phase of H1N1 Influenza A pandemia in Brazil and empirical oseltamivir was promptly initiated. H1N1 influenza A virus was detected on a nasopharyngeal swab using RT-PCR. On the $4^{\text {th }}$ ICU day, after significant reduction of vasopressors, the patient had paroxysms of acute atrial fibrillation and hemodynamic deterioration. Soon after, the electrocardiogram (EKG) showed diffuse ST-segment elevation (Figure 1) and the echocardiography (ECHO) disclosed mild left ventricular enlargement and hypocontractility of apical and medial segments in the septal, inferior, posterior and anterior wall. Left ventricular ejection fraction was 48\% (normal range above 55\%). Pericardium was normal. Troponin analysis showed marked elevation without a rise and fall pattern: $0.06 \rightarrow 2.02 \rightarrow$ $1.04 \rightarrow 1.64 \rightarrow 1.36(\mathrm{ng} / \mathrm{mL}$; normal range: $<0.03 \mathrm{ng} / \mathrm{mL})$. Hemodynamic support for distributive shock was maintained and continuous intravenous amiodarone infusion was initiated. During the following 12 hours the diffuse ST elevation in the EKG progressively resolved, without new $Q$ waves. A new ECHO was repeated after a week and left ventricular contractility and function had completely recovered. The patient's condition slowly improved, renal function recovered and he was successfully weaned from mechanical ventilation. He was discharged from hospital without cardiac sequelae.

Myocarditis has been associated with several viral infections, including influenza. Although the vast majority of patients present subclinical symptoms ${ }^{1}$, massive and fatal myocarditis has been described in previous influenza A outbreaks ${ }^{2,3}$. In this year, the first report of acute myocarditis associated with $\mathrm{H} 1 \mathrm{~N} 1$ influenza A infection in a pediatric population was published ${ }^{4}$, and to our knowledge, this is the first case of myocarditis in an adult related to 2009 pandemic influenza A H1N1 infection. We did

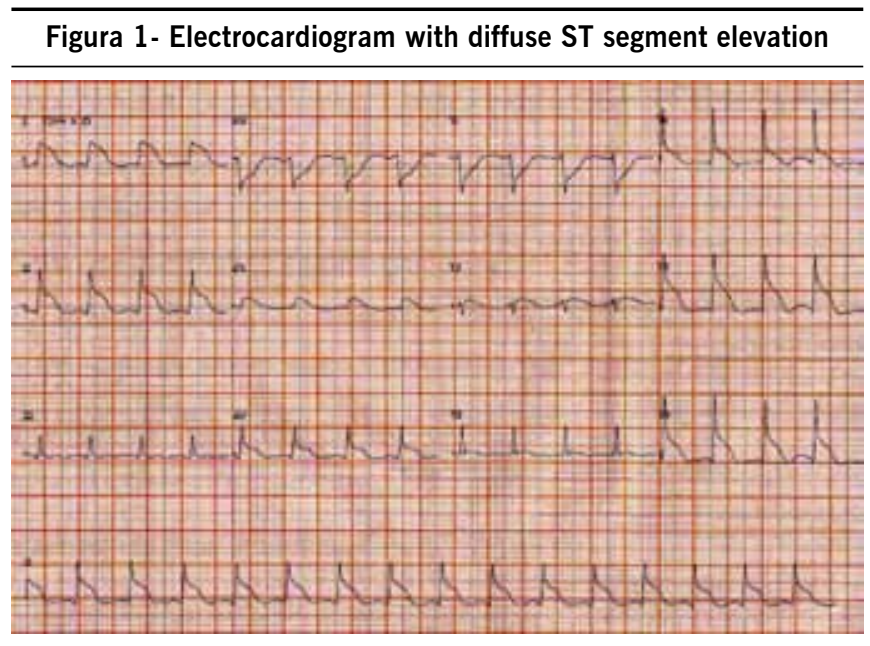

not have an histological sample to confirm our diagnosis, but the EKG and ECHO findings, added to the troponin behaviour and clinical evolution, strongly support the diagnosis of myocarditis. Although there were no cardiac sequelae in this case, we stress the importance of cardiac evaluation for patients with severe influenza A H1N1 infection.

\section{REFERENCES}

1. Mamas MA, Fraser D, Neyses L. Cardiovascular manifestations associated with influenza virus infection. Int J Cardiol. 2008;130:304-9.

2. Onitsuka H, Imamura T, Miyamoto N, Shibata Y, Kashiwagi T, Ayabe T, et al. Clinical manifestation of influenza A myocarditis during the influenza Epidemic of winter 1998-1999. J Cardiol. 2001;37(6):315-23

3. Nolte KB, Alakija P, Oty G, Shaw MW, Subbarao K, Guarner J, et al. Influenza A virus infection complicated by fatal myocarditis. Am J Forensic Med Pathol. 2000;21(4):375-9.

4. Bratincsák A, El-Said HG, Bradley JS, Shayan K, Grossfeld PD, Cannavino CR. .Fulminant myocarditis associated with pandemic $\mathrm{H} 1 \mathrm{~N} 1$ influenza $A$ virus in children. J Am Coll Cardiol. 2010;55(9):928-9

\section{*Correspondência:}

Incor

Av. Dr. Eneas Carvalho de Aguiar, 44

São Paulo - SP

05403-000

daniela.calderaro@incor.usp.br

1. Doutora em Medicina - Médica Assistente do Instituto do Coração da Faculdade de Medicina da Universidade de São Paulo - FMUSP, São Paulo, SP

2. Doutora em Medicina pela Faculdade de Medicina da Universidade de São Paulo - FMUSP e Médica Assistente da Divisão de Moléstias Infecciosas do Hospital das Clínicas- FMUSP, São Paulo, SP

3. Médica Residente da Divisão de Moléstias Infecciosas do Hospital das Clínicas- Faculdade de Medicina da Universidade de São Paulo - FMUSP, São Paulo, SP

4. Médica Assistente do Instituto do Coração da Faculdade de Medicina da Universidade de São Paulo - FMUSP, São Paulo, SP

5. Médico residente do Instituto do Coração da Faculdade de Medicina da Universidade de São Paulo - FMUSP, São Paulo, SP

6. Médica Assistente do Instituto do Coração da Faculdade de Medicina da Universidade de São Paulo - FMUSP, São Paulo, SP

7. Professor Doutor; Médico Diretor da Unidade de Medicina Interdisciplinar em Cardiologia do Instituto do Coração pela Faculdade de Medicina da Universidade de São Paulo - FMUSP, São Paulo, SP

8. Médica Assistente da Divisão de Moléstias Infecciosas do Hospital das Clínicas- Faculdade de Medicina da Universidade de São Paulo - FMUSP, São Paulo, SP 